\title{
Methods Evaluation for Rapid Concentration and Quantification of SARS-CoV-2 in Raw Wastewater Using Droplet Digital and Quantitative RT-PCR
}

\author{
Matthew T. Flood ${ }^{1} \cdot$ Nishita D'Souza ${ }^{1} \cdot$ Joan B. Rose ${ }^{1} \cdot$ Tiong Gim Aw ${ }^{2}$ (D)
}

Received: 28 February 2021 / Accepted: 13 July 2021 / Published online: 22 July 2021

(c) The Author(s), under exclusive licence to Springer Science+Business Media, LLC, part of Springer Nature 2021

\begin{abstract}
Wastewater surveillance of severe acute respiratory syndrome coronavirus 2 (SARS-CoV-2) is an emerging public health tool to understand the spread of Coronavirus Disease 2019 (COVID-19) in communities. The performance of different virus concentration methods and PCR methods needs to be evaluated to ascertain their suitability for use in the detection of SARS-CoV-2 in wastewater. We evaluated ultrafiltration and polyethylene glycol (PEG) precipitation methods to concentrate SARS-CoV-2 from sewage in wastewater treatment plants and upstream in the wastewater network (e.g., manholes, lift stations). Recovery of viruses by different concentration methods was determined using Phi6 bacteriophage as a surrogate for enveloped viruses. Additionally, the presence of SARS-CoV-2 in all wastewater samples was determined using reverse transcription quantitative PCR (RT-qPCR) and reverse transcription droplet digital PCR (RT-ddPCR), targeting three genetic markers (N1, N2 and E). Using spiked samples, the Phi6 recoveries were estimated at 2.6-11.6\% using ultrafiltration-based methods and 22.2-51.5\% using PEG precipitation. There was no significant difference in recovery efficiencies $(\mathrm{p}<0.05)$ between the PEG procedure with and without a $16 \mathrm{~h}$ overnight incubation, demonstrating the feasibility of obtaining same day results. The SARS-CoV-2 genetic markers were more often detected by RT-ddPCR than RT-qPCR with higher sensitivity and precision. While all three SARS-CoV-2 genetic markers were detected using RT-ddPCR, the levels of E gene were almost below the limit of detection using RT-qPCR. Collectively, our study suggested PEG precipitation is an effective low-cost procedure which allows a large number of samples to be processed simultaneously in a routine wastewater monitoring for SARS-CoV-2. RT-ddPCR can be implemented for the absolute quantification of SARS-CoV-2 genetic markers in different wastewater matrices.
\end{abstract}

Keywords SARS-CoV-2 · Coronavirus · PEG precipitation · RT-ddPCR · RT-qPCR · Wastewater-based epidemiology

\section{Introduction}

Since the emergence and spread of severe acute respiratory syndrome coronavirus 2 (SARS-CoV-2), the virus that causes coronavirus disease 2019 (COVID-19), many cities around the world have rapidly expanded their viral surveillance systems, including wastewater monitoring for

Tiong Gim Aw

taw@tulane.edu

1 Department of Fisheries and Wildlife, Michigan State University, East Lansing, MI 48824, USA

2 Department of Environmental Health Sciences, School of Public Health and Tropical Medicine, Tulane University, 1440 Canal Street, Suite 2100, New Orleans, LA 70112, USA
SARS-CoV-2. This is because SARS-CoV-2 can be shed in the feces of infected individuals from both symptomatic and asymptomatic cases (Park et al., 2020; Wu et al., 2020a, 2020b).

Coronaviruses are positive-strand RNA enveloped viruses with the largest viral genomes of all RNA viruses (27 to $32 \mathrm{~kb}$ ). They have a spherical virion of about $120 \mathrm{~nm}$ in diameter surrounded by a lipid envelope with pronounced spiked glycoproteins (S) embedded. The vast majority of studies on the presence of viruses in human excreta and municipal wastewater have been focused on non-enveloped enteric viruses. There are a number of established methods for the detection of non-enveloped enteric viruses in wastewater, but only fewer evaluated protocols for human enveloped viruses such as SARS-CoV-2 (Haramoto et al., 2018). Analysis of environmental matrices for human viruses often 
require concentration steps due to the low ambient concentrations of the viruses. Therefore, laboratory methods for the detection of SARS-CoV-2 in wastewater need to examine both sample concentration and RNA quantification methods along with optimizing limits of detection.

Globally, there have been over forty reports on the molecular detection of SARS-CoV-2 in wastewater (e.g., Ahmed et al., 2020a; Ahmed et al., 2020b; Ampuero et al., 2020; Arora et al., 2020; Balboa et al., 2020; Barcelo, 2020; Chavarria-Miró et al., 2020; Curtis et al., 2020; Döhla et al., 2020; Fernández de Mera et al., 2020; Fongaro et al., 2020; Green et al., 2020; Guerrero-Latorre et al., 2020; Haramoto et al., 2020; Hata et al., 2020; Jorgensen et al., 2020; Kocamemi et al., 2020a; Kocamemi et al., 2020b; Kumar et al., 2020; La Rosa et al., 2020a, 2020b, 2020c; Medema et al., 2020; Miyani et al., 2020; Nemudryi et al., 2020; Bar-Or et al., 2020; Peccia et al., 2020; Prado et al., 2020; Randazzo et al., 2020a; Randazzo et al., 2020b; Rimoldi et al., 2020; Sharif et al., 2020; Sherchan et al., 2020; Trottier et al., 2020; Vallejo et al., 2020; Wang et al., 2020; Weidhaas et al., 2020; Westhaus et al., 2021; Wu et al., 2020a; Wu et al., 2020b; Wurtzer et al., 2020; Zhang et al., 2020a; Zhang et al., 2020b; Zhou et al., 2020). These studies have had large variability in the numbers of samples from as few as 10 samples collected to over 120 with SARSCoV-2 RNA being detected at concentrations ranging from $10^{2}$ to $10^{6}$ copies per liter. These SARS-CoV-2 surveillance studies analyzed volumes of raw sewage, treated wastewater and sewage sludge ranging from 2.5 to $2000 \mathrm{ml}$, using various concentration methods such as adsorption-elution-based membrane filtration, precipitation (using polyethylene glycol, aluminum hydroxide), ultracentrifugation and ultrafiltration prior to RNA extraction in order to recover the virus. The majority of studies quantified the viral RNA in wastewater using quantitative reverse transcription polymerase chain reaction (RT-qPCR) with external standard curves. Several gene targets specific to the SARS-CoV-2 have been used in wastewater surveillance, including the RNA-dependent polymerase (RdRP), nucleocapsid (N1, N2), envelope protein (E), spike glycoprotein (S), membrane glycoprotein (M) and ORF1ab genes (e.g., Corman et al., 2020; Lu et al., 2020).

Currently, cell culture for SARS-CoV-2 requires a Biosafety Level 3 laboratory and specially trained personnel. Therefore, surrogate viruses have been used to mimic SARS-CoV-2 to evaluate virus concentration methods for wastewater. These surrogate viruses include F-specific RNA phages (Balboa et al., 2020; Hata et al., 2020; Medema et al., 2020), mengovirus (Randazzo et al., 2020a), avian coronavirus of infectious bronchitis virus (Kocamemi et al., 2020a), Alphacoronavirus HCoV 229E (La Rosa et al., 2020b), bovine coronavirus BCoV (LaTurner et al., 2021), porcine epidemic diarrhea virus (PEDV) (Randazzo et al., 2020b), bovine respiratory syncytial virus (BRSV) (Gonzalez et al., 2020), and murine hepatitis virus (Ahmed et al., 2020c). Estimated mean recovery efficiencies for these surrogate viruses ranged from 1 to $73 \%$ using different concentration methods originally developed for the detection of enteric viruses in environmental samples (Medema et al., 2020; Randazzo et al., 2020a). Pseudomonas phage Phi6 has also been used as a model enveloped virus in recovery and persistence studies (Gendron et al., 2010; Aquino de Carvalho et al., 2017; Ye et al., 2016). Similar to coronaviruses, Phi6 is an enveloped RNA virus, with a segmented genome and glycerophospholipids in its envelope (Vidaver et al., 1973). Since Phi6 is not pathogenic to humans, it is easier to work with than other enveloped animal viruses and no special laboratory biosafety is required.

Rapid, cost-effective, and efficient methods are needed to provide precise data to support public health decision making. This is so that changes in concentrations of SARS-CoV-2 gene markers in wastewater provide meaningful data to inform COVID-19 surveillance. Therefore, the objectives of this study were to (i) evaluate the efficiencies of polyethylene glycol (PEG) precipitation and ultrafiltration methods to recover Pseudomonas phage Phi6, coronavirus OC43, and SARS-CoV-2 from different wastewater matrices; (ii) compare two PCR-based methods, reverse transcription quantitative PCR (RT-qPCR) and reverse transcription droplet digital PCR (RT-ddPCR) for the detection of SARS-CoV-2 in different wastewater matrices; and (iii) develop a rapid, cost-effective, and precise quantification workflow for SARS-CoV-2 in wastewater.

\section{Materials and Methods}

\section{Wastewater Samples and Sampling Sites}

Wastewater samples $(500-1000 \mathrm{ml})$ for this study were collected from 11 sanitary sewer sites and four wastewater treatment plant (WWTP) influent streams (after grit removal) (Supplemental materials Table A1 and A2). A total of twenty sanitary sewer samples were collected as grab samples from the 11 manholes or lift stations. Sanitary sewer samples consisted of wastewater flowing from university dormitories, local communities, and hospital. Influent samples $(n=11)$ from four WWTPs were collected as 24-h composite samples. Samples used for the comparison of the SARS-CoV-2 surrogates Phi6 and human coronavirus OC43 were collected from two California wastewater treatment plant influents as previously described by Pecson et al. (2021). All samples were kept at $4{ }^{\circ} \mathrm{C}$ for up to $72 \mathrm{~h}$. If samples were unable to be processed 
within $72 \mathrm{~h}$ of collection, then they were frozen at $-80^{\circ} \mathrm{C}$ until analysis.

\section{Virus Stocks}

Bacteriophage Phi6 and its bacterial host Pseudomonas syringae were kindly provided by Dr. Krista Wigginton's lab at University of Michigan. To propagate Phi6, P. syringae was grown in King's B medium at $24{ }^{\circ} \mathrm{C}$ for $6 \mathrm{~h}$ in stationary culture. Phi6 was added to the host and incubated under the same conditions for 16 to $18 \mathrm{~h}$. After incubation and observed clearing of cell suspension due to lysis, cells and debris were removed from the Phi6 suspension by filtration using $0.22 \mu \mathrm{m}$ membranes. The Phi6 stocks were stored at $4{ }^{\circ} \mathrm{C}$ and titered using an overlay method. For the overlay process, $2 \mathrm{ml}$ of host was added to the overlay tube containing King's B agar and $0.5 \mathrm{ml}$ of virus suspension, mixed, and poured onto a plate containing King's B agar. Plates were incubated at $24{ }^{\circ} \mathrm{C}$ for $16-24 \mathrm{~h}$ and plaques were counted. Virus titers of approximately $10^{9}$ plaque forming unit (PFU) per $\mathrm{ml}$ were routinely obtained.

\section{Virus Concentration Methods and Experiments}

Four distinct comparisons were performed in this study. First, three viral concentration methods were tested for their efficiency in recovering Phi6 phages and SARS-CoV-2 in different types of wastewater. Methods 1 (CEN1) and 2 (CEN2) are based on the ultrafiltration principle and used centrifugal filters. Method 3 is a precipitation using polyethylene glycol (PEG). The second comparison was between RT-ddPCR and qPCR using the three viral concentration methods. The third comparison was determining if a rapid PEG precipitation approach (without an overnight incubation) would be able to perform as well or better than PEG precipitation with a $16 \mathrm{~h}$ overnight incubation. Lastly, Phi6 was compared against the human coronavirus OC43 using RT-ddPCR to determine if recovery efficiencies between the two SARS-CoV-2 surrogates were equivalent.

For each experiment, $350 \mathrm{ml}$ of wastewater sample was inoculated with $1 \mathrm{ml}$ of $10^{6}$ plaque forming units (PFU)/ $\mathrm{ml}$ of Phi6 and homogenized for $10 \mathrm{~min}$ at $4{ }^{\circ} \mathrm{C}$. SARSCoV-2 was not added to the sample. After homogenization, the sample was subdivided into three $101 \mathrm{ml}$ of aliquots in $250 \mathrm{ml}$ centrifuge bottles for processing with each concentration method. One milliliter of sample was removed from each $250 \mathrm{ml}$ bottle containing the subsample for use in determining the seeded virus level for recovery efficiency of each method. Recovery efficiencies were determined by comparing the concentration of the spiked Phi6 bacteriophage in each subsample prior to processing with the concentration of Phi6 in their final concentrate using RT-ddPCR. All viral concentration experiments, for each method and each type of wastewater, were conducted in triplicate.

Method 1 (CEN1) was adapted from Ye et al. (2016) but modified to include virus recovery steps from wastewater solids. Briefly, $100 \mathrm{ml}$ of wastewater sample was first centrifuged at $2500 \times g$ for $5 \mathrm{~min}$ at $4{ }^{\circ} \mathrm{C}$ in order to pellet any solids present in the sample. The supernatant was then collected without disturbing the pellet and filtered through a $0.22 \mu \mathrm{m}$ polyethersulfone (PES) membrane filter (MilliporeSigma, St. Louis, MO). The sample was then concentrated using a $10 \mathrm{kDa}$ Centricon Plus-70 centrifugal filter unit (MilliporeSigma, St. Louis, MO) according to the manufacturer's protocol. A 1:1 volume of $0.25 \mathrm{~N}$ glycine buffer was added to the pellet and remaining liquid. The pellet was vortexed every $10 \mathrm{~min}$ for $30 \mathrm{~min}$ while on ice to dislodge the viruses from suspended solids. After the 30 min incubation the glycine-processed sample was neutralized 1:1 with $2 \times$ PBS. The sample was then centrifuged at $10,000 \times g$ for $30 \mathrm{~min}$ at $4{ }^{\circ} \mathrm{C}$. The supernatant was processed with the same centrifugal filter and the resulting concentrates were combined.

Method 2 (CEN2) involved the use of the same centrifugal filter but without a pre-filtration step (Medema et al., 2020). In this method, $100 \mathrm{ml}$ of sample was centrifuged at $4654 \times \mathrm{g}$ for $30 \mathrm{~min}$ at $4{ }^{\circ} \mathrm{C}$ without brake. The supernatant was then collected and directly filtered through a $10 \mathrm{kDa}$ Centricon Plus-70 centrifugal filter unit (MilliporeSigma, St. Louis, MO) according to the manufacturer's protocol. The pellet was processed using the same protocol as described in the Method 1 (CEN1).

Method 3 (PEG) was adapted from Borchardt et al. (2017) for the detection of avian influenza virus RNA in groundwater. The samples were mixed with $8 \%$ (w/vol) molecular biology grade PEG 8000 (Promega Corporation, Madison $\mathrm{WI})$ and $0.2 \mathrm{M} \mathrm{NaCl}(\mathrm{w} / \mathrm{v})$. The samples were mixed slowly on magnetic stirrer at $4{ }^{\circ} \mathrm{C}$ for $2 \mathrm{~h}$ and then held at $4{ }^{\circ} \mathrm{C}$ for $16 \mathrm{~h}$. Following the overnight incubation, samples were centrifuged at $4700 \times g$ for $45 \mathrm{~min}$ at $4{ }^{\circ} \mathrm{C}$. The supernatant was then removed, and the pellet resuspend in the remaining liquid. All sample concentrates were aliquoted and stored at $-80{ }^{\circ} \mathrm{C}$ until further processing.

After the initial comparison of two ultrafiltration methods and PEG precipitation, a rapid PEG precipitation approach (without an overnight incubation) was evaluated with 19 wastewater samples. Each sample was inoculated with Phi6 and homogenized as described above. After mixing the sample with $8 \%(\mathrm{w} / \mathrm{vol}$ ) PEG 8000 and $0.2 \mathrm{M} \mathrm{NaCl}$ for $2 \mathrm{~h}$ at $4{ }^{\circ} \mathrm{C}$, the sample was immediately centrifuged at $4700 \times g$ for $45 \mathrm{~min}$ at $4{ }^{\circ} \mathrm{C}$.

Finally, a comparison between Phi6 and OC43 was performed using wastewater from two California wastewater treatment plants split into 5 subsamples each and processed with the overnight PEG precipitation method. 


\section{RNA Extraction and Quantification by RT-ddPCR and RT-qPCR}

Viral ribonucleic acid (RNA) was extracted from wastewater concentrates using the Qiagen QIAmp Viral RNA Minikit according to the manufacturers protocol with modifications (Qiagen, Germany). In this study, a total of $200 \mu \mathrm{l}$ of concentrate was used for RNA extraction resulting in a final elution volume of $80 \mu \mathrm{l}$. Extracted RNA was stored at $-80^{\circ} \mathrm{C}$ until analysis.

\section{Detection of SARS-CoV-2, Phi6, and Coronavirus OC43 Using RT-ddPCR}

One-step RT-ddPCR approach was used to quantify the Phi6 RNA to determine the recovery efficiencies for each concentration method. All the primers and probes used in this study are listed in Table A3. Droplet digital PCR was performed using Bio-Rad's 1-Step RT-ddPCR Advanced kit with a QX200 ddPCR system (Bio-Rad, CA, USA). Each reaction contained a final concentration of $1 \times$ Supermix (Bio-Rad, CA, USA), 20 U ul-1 reverse transcriptase (RT) (Bio-Rad, CA, USA), $15 \mathrm{mM}$ DTT, $900 \mathrm{nmol} \mathrm{l}^{-1}$ of each primer, $250 \mathrm{nmol}^{-1}$ of each probe, $1 \mu \mathrm{l}$ of molecular grade RNAse-free water, and $5.5 \mu \mathrm{l}$ of template RNA for a final reaction volume of $22 \mu \mathrm{l}$. Droplet generation was performed by microfluidic mixing of $20 \mu \mathrm{l}$ of each reaction mixture with $70 \mu \mathrm{l}$ of droplet generation oil in a droplet generator (Bio-Rad, CA, USA) resulting in a final volume of $40 \mu \mathrm{l}$ of reaction mixture-oil emulsions containing up to 20,000 droplets with a minimum droplet count of $>9000$. The resulting droplets were then transferred to a 96-well PCR plate which was heat-sealed with foil and placed into a C1000 96-deep-well thermocycler (Bio-Rad, CA, USA) for PCR amplification using the following parameters: $25{ }^{\circ} \mathrm{C}$ for $3 \mathrm{~min}, 50{ }^{\circ} \mathrm{C}$ for $1 \mathrm{~h}, 95{ }^{\circ} \mathrm{C}$ for $10 \mathrm{~min}$, followed by 40 cycles of $95{ }^{\circ} \mathrm{C}$ for $30 \mathrm{~s}$ and $60{ }^{\circ} \mathrm{C}$ for $1 \mathrm{~min}$ with ramp rate of $2{ }^{\circ} \mathrm{C} \mathrm{s} 1$ followed by a final cycle of $98{ }^{\circ} \mathrm{C}$ for $10 \mathrm{~min}$. Following PCR thermocycling, each 96-well plate was transferred to a QX200 Droplet Reader (Bio-Rad, CA, USA) for the concentration determination through the detection of positive droplets containing each gene target by spectrophotometric detection of the fluorescent probe signal.

SARS-CoV-2 RNA and OC43 in wastewater samples were also quantified using the same one-step RT-ddPCR approach except the annealing temperature was set at $55^{\circ} \mathrm{C}$. Three SARS-CoV-2 markers were chosen for analysis, the nucleocapsid 1 (N1) and nucleocapsid 2 (N2) gene targets designed by the US Centers for Disease Control and Prevention (CDC) (Lu et al., 2020), the envelope (E) gene from Corman et al. (2020), and OC43 (Table A3). The N1 and N2 gene targets were analyzed in a duplex assay. All analyses were run in triplicate for each marker. Quality controls were run with every plate including positive and non-template controls, extraction controls, and processing blanks for each batch of samples.

\section{Detection of SARS-CoV-2 Using RT-qPCR}

RT-qPCR approach was also used to quantify SARS-CoV-2 gene markers in wastewater samples. All RT-qPCR reactions were performed using a StepOne Plus ${ }^{\mathrm{TM}}$ real-time PCR sequence detector (Applied Biosystems, Foster City, CA). For each assay, a tenfold diluted standard curve of at least five points, a non-template control, and samples were tested in triplicate. The quantitative synthetic SARS-CoV-2 RNA includes fragments from nucleocapsid and envelope regions (ATCC VR-3276SD) was used to generate standard curves. Amplification reaction mixtures (final total volume of $20 \mu \mathrm{l}$ ) contained $5 \mu \mathrm{l}$ template RNA, $10 \mu \mathrm{l}$ of $2 \times$ qScript one-step RT-qPCR ToughMix (QuantaBio), $300 \mathrm{nM}, 500 \mathrm{nM}$ and $400 \mathrm{nM}$ of forward primer for N1, N2, and E gene, respectively, $500 \mathrm{nM}, 800 \mathrm{nM}$, and $800 \mathrm{nM}$ of reverse primer for $\mathrm{N} 1, \mathrm{~N} 2$, and $\mathrm{E}$ gene, respectively, and $200 \mathrm{nM}$ of probe. The thermal cycling protocol was as follows: $10 \mathrm{~min}$ at $50{ }^{\circ} \mathrm{C}$ for cDNA synthesis, $3 \mathrm{~min}$ at $95{ }^{\circ} \mathrm{C}$ for initial denaturation, followed by 45 cycles of two steps consisting of $3 \mathrm{~s}$ at $95{ }^{\circ} \mathrm{C}$ and $30 \mathrm{~s}$ at $55^{\circ} \mathrm{C}$. qPCR amplification efficiencies for the quantification of the N1, N2 and $\mathrm{E}$ gene assays were $92.6 \pm 4.3 \%, 95.1 \pm 3.4 \%$, and $91.6 \pm 2.2 \%$, respectively, and the correlation coefficients $\left(\mathrm{R}^{2}\right)$ of the standard curves were $0.968 \pm 0.002,0.982 \pm 0.004$, and $0.988 \pm 0.0006$, respectively.

\section{Data Analysis}

All SARS-CoV-2, Phi6, and OC43 gene data were converted from gene copies (GC) per reaction to GC per $100 \mathrm{ml}$ before analysis. Non-detects (ND) were assigned their individual sample's limit of detection. The limit of detection was calculated for each individual sample based on both the molecular assays' theoretical detection limits (i.e., 3 positive droplets for RT-ddPCR; the lowest standard curve concentration for RT-qPCR) and the concentration factor of each processing method examined.

Virus GC per100 $\mathrm{ml}=\frac{\frac{\mathrm{GC} \text { per reaction }}{V_{\mathrm{r}}} \times V_{\mathrm{e}} \times \frac{V_{\mathrm{f}}}{V_{\mathrm{c}}}}{V_{\mathrm{i}}} \times 100$

where: $V_{\mathrm{i}}=$ Initial volume of sample concentration in $\mathrm{ml}$, $V_{\mathrm{f}}=$ Final volume of sample after concentration in $\mathrm{ml}$, $V_{\mathrm{r}}=$ Volume of RNA template used per PCR reaction in $\mu$, $V_{\mathrm{e}}=$ Final volume of RNA eluted from RNA extraction in $\mu \mathrm{l}$, 
$V_{\mathrm{c}}=$ Volume of concentrated sample used for RNA extraction in $\mathrm{ml}$.

Recovery efficiency was calculated by dividing the total gene copies (GC) / $100 \mathrm{ml}$ concentration of the Phi6 bacteriophage measured in each methods' final concentrate by the concentration $(\mathrm{GC} / 100 \mathrm{ml})$ of Phi6 in each sample before concentration and then multiplying by 100 .

Statistics and data visualization were performed using Graphpad Prism 8 (Graphpad Software, CA, USA). Results for the three methods comparison were analyzed with a two-way ANOVA with a Tukey's multiple comparisons test to determine method significance ( $\mathrm{p}$-value $<0.05$ ). A twoway ANOVA $(\mathrm{p}<0.05)$ and a paired $\mathrm{t}$ test $(\mathrm{p}<0.05)$ were performed for the comparison of "normal" ( $16 \mathrm{~h}$ hold) vs "rapid" (no hold) PEG precipitation methods.

\section{Results}

\section{Wastewater Characteristics}

Wastewater samples from both sanitary sewer systems and treatment plants were evaluated in this study. All site-specific details including physiochemical data and sampling dates for each sanitary sewer and WWTP site are shown in Table A1 and Table A2, respectively. Wastewater collected from sanitary sewer locations had more variations in each parameter than wastewater collected from WWTP. For example, while sanitary sewer sites showed a wide range of turbidities ranging from 1.87 up to 191 NTU, WWTP influent samples showed less variation (e.g., 20.2 to 111 NTU). Sanitary sewer sites showed little variation in $\mathrm{pH}$ and temperature with each ranging from $6.57-8.58$ and $13-26.4^{\circ} \mathrm{C}$, respectively (Table A1). Influent samples collected from WWTPs had a smaller degree of variation in $\mathrm{pH}$ (7.33-7.8) than sanitary sewer sites but had greater variation in temperatures which ranged from 1.40 to $21.67^{\circ} \mathrm{C}$ (Table A2). Total suspended solids (TSS) and daily flows for each WWTP were also measured. Specifically, samples collected from facility W had the largest range of TSS (48-920 $\mathrm{mg} \mathrm{l}^{-1}$ ) and the highest daily flows ranging from 14.6-27.6 million gallons per day (mgd). Facility $\mathrm{E}$ had the smallest range of TSS (164-208 $\mathrm{mg} \mathrm{l}^{-1}$ ) and the lowest daily flow of $2.87 \mathrm{mgd}$, but facility $\mathrm{M}$ had the smallest range of daily flows (3.24-3.86 mgd).

\section{Recovery of Phi6 from Wastewater Samples Using Ultrafiltration and PEG Methods}

Prior to seeding experiments, ambient concentrations of Pseudomonas phage Phi6 were determined using RTddPCR. All wastewater samples were negative for Phi6.

The mean recovery efficiencies of the two ultrafiltrationbased and PEG precipitation methods for the detection of Phi6 using RT-ddPCR in different types of wastewater are summarized in Table 1. For the various wastewater matrices, mean recoveries of ultrafiltration-based Method 1 ranged from 2.6 to $10.6 \%$ and Method 2 ranged from 2.7 to $11.6 \%$. The Phi6 virus recovery was statistically higher $(\mathrm{p}<0.0001)$ for both sanitary sewers and WWTP influent samples using the PEG method compared to the ultrafiltration methods, with mean recoveries ranging from 22.19 to $51.47 \%$ (Table 1).

The source of wastewater had no significant impact (twoway anova, $\mathrm{n}=18$, $\mathrm{p}$-value $=0.4736$ ) on the recovery efficiency of Phi6, regardless of the virus concentration method yet more variability was seen when testing sanitary sewer samples using PEG (Table A4).

\section{Detection of SARS-CoV-2 in Wastewater Samples Using Ultrafiltration and PEG methods}

All wastewater samples using the three concentration methods were also analyzed for SARS-CoV-2 using RT-ddPCR and RT-qPCR. The N1 and N2 gene targets showed similar results between the two PCR methods (Table 2). While the
Table 1 Recovery efficiencies of ultrafiltration and PEG methods for the detection of Phi6 in seeded wastewater samples

\begin{tabular}{llccl}
\hline Wastewater Type & Sampling site $(\mathrm{n}=\mathrm{x})$ & \multicolumn{2}{l}{$\begin{array}{l}\text { Phi6 phage recovery as measured by RT-ddPCR } \\
\text { Mean } \pm \text { SD \% (range) }\end{array}$} \\
\cline { 3 - 5 } & & Method 1/CEN1 & Method 2/ CEN2 & Method 3/PEG \\
\hline Sanitary Sewer & Hospital Lift Station (3) & $9.59 \pm 1.14$ & $4.99 \pm 0.04$ & $51.47 \pm 26.08$ \\
& & $(8.90-10.91)$ & $(4.95-5.02)$ & $(26.52-78.55)$ \\
& Community manhole (6) & $10.60 \pm 14.58$ & $11.64 \pm 6.05$ & $25.49 \pm 18.46$ \\
& & $(1.98-39.9)$ & $(5.77-22.07)$ & $(3.93-47.49)$ \\
Wastewater & WWTP A (3) & $6.05 \pm 4.89$ & $2.73 \pm 2.04$ & $36.01 \pm 19.41$ \\
Treatment Plant & & $(0.48-9.64)$ & $(1.23-5.05)$ & $(23.03-58.33)$ \\
Influent & WWTP E (3) & $9.25 \pm 15.72$ & $9.21 \pm 15.37$ & $31.98 \pm 7.52$ \\
& & $(0.05-27.41)$ & $(0.10-26.95)$ & $(23.57-38.07)$ \\
& WWTP M (3) & $2.60 \pm 1.39$ & $10.37 \pm 12.61$ & $22.19 \pm 15.72$ \\
& & $(1.03-3.64)$ & $(0.87-24.68)$ & $(4.67-35.04)$ \\
\hline
\end{tabular}




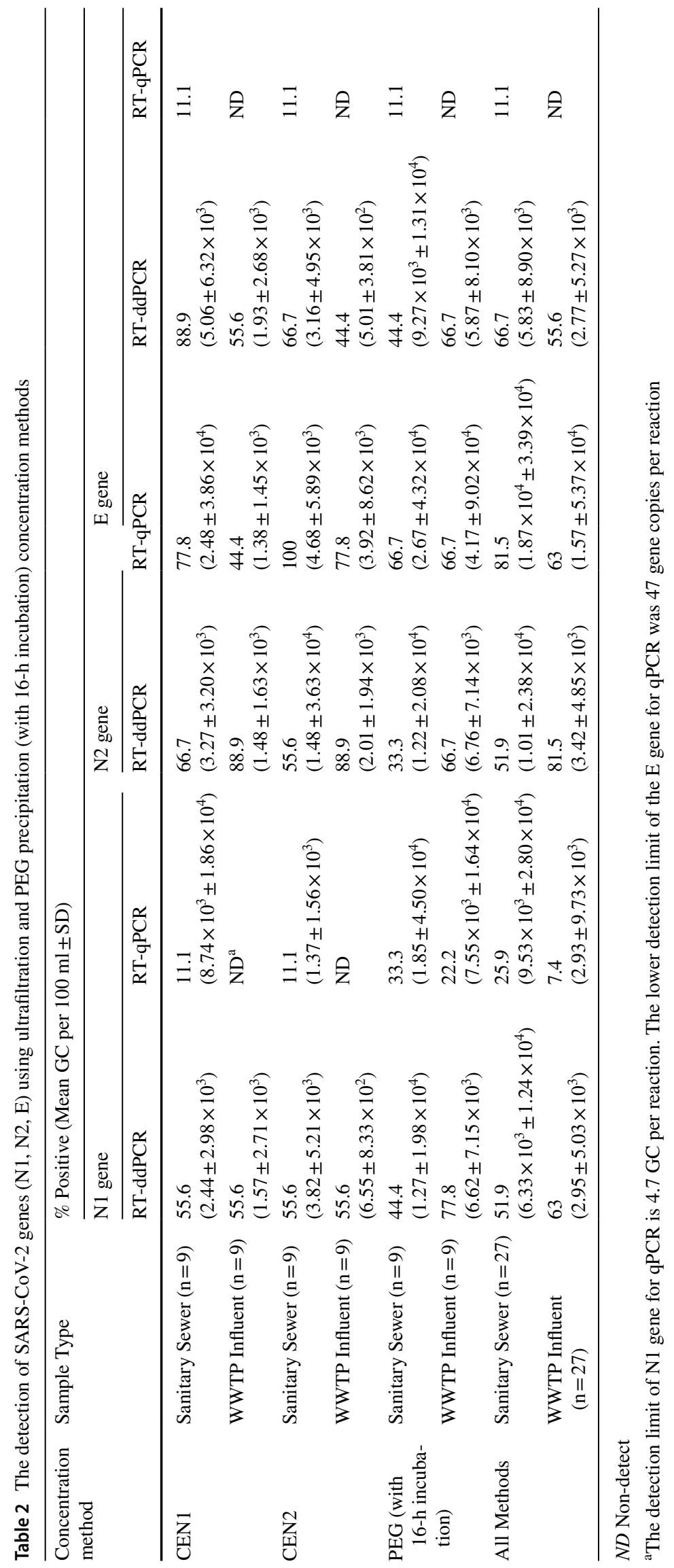


E gene target performed satisfactorily on the RT-ddPCR platform, it showed poor results on the RT-qPCR platform with nearly all samples being identified as non-detects with no detected samples above the lower limit of quantification (LLOQ) (Table 2). The N2 gene target performed the best overall for the RT-qPCR assay. Using RT-ddPCR, the N1, N2, and E gene performed similarly with coefficients of variation for their detection of SARS-CoV-2 of 0.03 and 0.20 for sanitary sewer and WWTP influent samples, respectively (Table 2). Across three concentration methods RT-ddPCR showed fairly consistent patterns of SARS-CoV-2 detection, while the RT-qPCR assays relied heavily on the $\mathrm{N} 2$ gene target for SARS-CoV-2 detection (Table 2). Overall RT-ddPCR performed better at detecting SARS-CoV-2 gene targets than RT-qPCR in the wastewater samples tested with the exception of the N2 gene target in sanitary sewer samples which performed better with RTqPCR (Table 2).
The overall concentrations of SARS-CoV-2 measured by RT-ddPCR for the three gene targets $(\mathrm{N} 1, \mathrm{~N} 2, \mathrm{E})$ ranged from $<$ LLOD $-5.71 \times 10^{4} \mathrm{GC} / 100 \mathrm{ml},<$ LLOD $-1.11 \times 10^{5}$ $\mathrm{GC} / 100 \mathrm{ml}$, and $<\mathrm{LLOD}-3.94 \times 10^{4} \mathrm{GC} / 100 \mathrm{ml}$, respectively (Table A3-A5). The overall concentrations of SARS-CoV-2 measured by RT-qPCR for the three gene targets (N1, N2, E) ranged from $<$ LLOD $-1.38 \times 10^{5} \mathrm{GC} / 100 \mathrm{ml},<$ LLOD$2.80 \times 10^{5} \mathrm{GC} / 100 \mathrm{ml}$, and $<$ LLOQ, respectively (Table A3-A5). Slightly higher concentrations of N2 gene target in sanitary sewer and WWTP influent samples were obtained using RT-qPCR as compared to RT-ddPCR (Table 2).

Higher precision between gene targets was observed in the sanitary sewer samples versus the WWTP influent samples for both RT-ddPCR and RT-qPCR (Fig. 1). RT-ddPCR showed significantly lower coefficients of variations for every combination of concentration method and sample type with the exception of WWTP influents processed by CEN2 and PEG (Fig. 1).
Fig. 1 Coefficients of variations for SARS-CoV-2 gene targets; a sanitary sewer samples, b WWTP influent samples, c sanitary sewer samples with all concentration methods, and d WWTP influent samples with all concentration methods. Twoway ANOVA analysis results shown above each graph; $n s$ Not significant, ${ }^{*}$-value $<0.05$, $* *$ p-value $<0.01$, $* * *$ p-value $<0.001, * * * *$ p-value $<0.0001$ a)

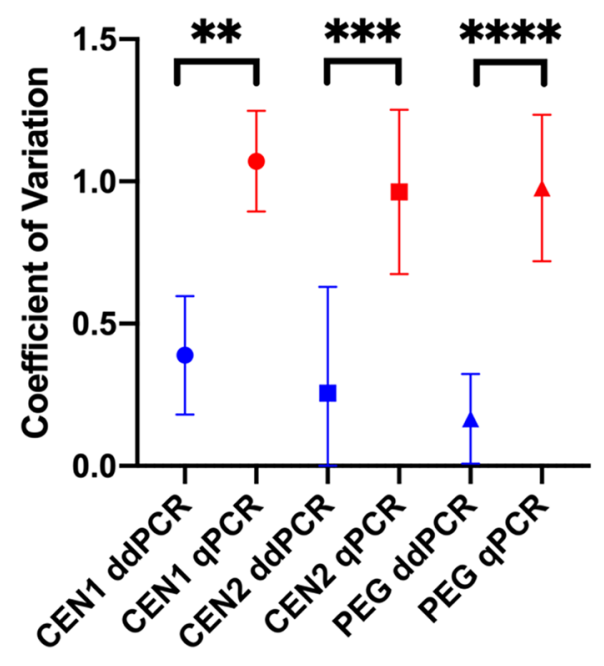

c)

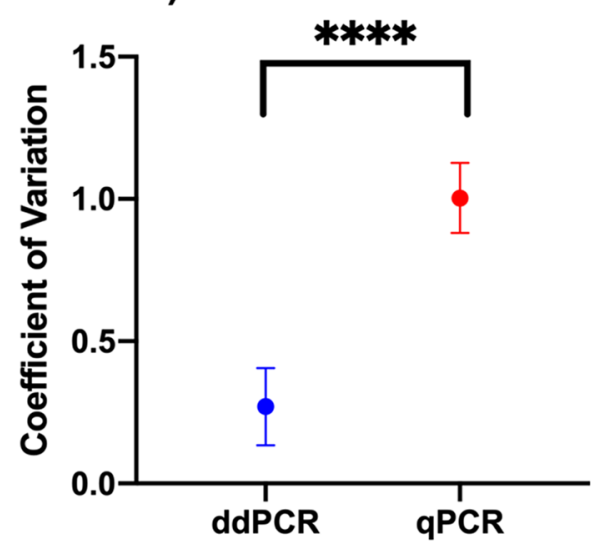

b)

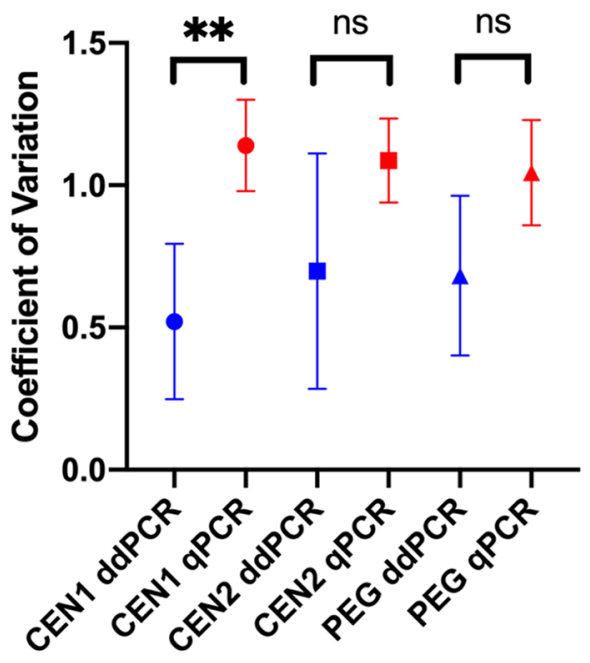

d)

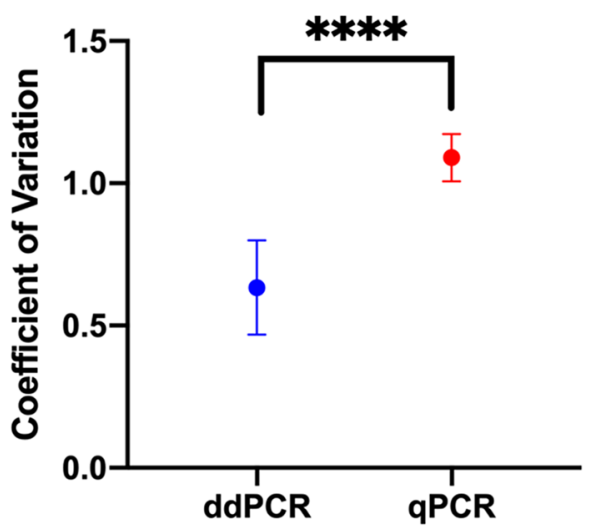




\section{Evaluation of Rapid PEG Approach for the Detection of Phi6 and SARS-CoV-2 in Wastewater}

Based on the comparison between ultrafiltration and PEG methods for wastewater, the PEG precipitation was evaluated further for the detection of Phi6 and SARS-CoV-2 with and without $16 \mathrm{~h}$ of incubation. As shown in Table 3, without an overnight incubation, the PEG method showed an average recovery efficiency of $18.8 \%$ for sanitary sewer and of $35 \%$ for WWTP influent samples. In general, this approach produced lower recovery for Phi6 as compared with the PEG with overnight incubation, regardless of the type of wastewater samples. However, the difference was not statistically significant (Table 3).

For the detection of SARS-CoV-2 using RT-ddPCR, comparable results were obtained for the N1 and N2 gene targets with and without overnight incubation (Table 4). However, the rapid PEG method produced a lower percentage of WWTP influent samples positive for the E gene. Average SARS-CoV-2 concentrations varied little between sample types, PEG methods (i.e., with and without overnight incubation), and gene targets using RT-ddPCR, ranging from $1.82 \pm 4.55 \times 10^{3} \mathrm{GC} / 100 \mathrm{ml}$ to $8.57 \times 10^{3} \pm 1.12 \times 10^{4}$ $\mathrm{GC} / 100 \mathrm{ml}$ (Table 4).

Table 3 Mean recovery efficiencies of Phi6 in seeded wastewater samples using PEG precipitation method with and without overnight incubation

\begin{tabular}{|c|c|c|}
\hline \multirow[t]{2}{*}{ Wastewater Type } & \multicolumn{2}{|c|}{ Phi6 mean recovery \pm SD $(\%)$} \\
\hline & $\begin{array}{l}\text { PEG with } \\
\text { overnight (16-h) } \\
\text { incubation }\end{array}$ & $\begin{array}{l}\text { Rapid PEG without } \\
\text { overnight incuba- } \\
\text { tion }\end{array}$ \\
\hline Sanitary Sewer $(n=15)$ & $32.07 \pm 23.23$ & $18.80 \pm 11.48$ \\
\hline WWTP Influent $(n=4)$ & $31.31 \pm 11.73$ & $34.99 \pm 26.38$ \\
\hline All Samples $(\mathrm{n}=19)$ & $31.92 \pm 21.27^{\mathrm{a}}$ & $21.89 \pm 15.88^{\mathrm{a}}$ \\
\hline
\end{tabular}

${ }^{a}$ No significant difference $(n=19, p=0.1048)$ in mean recovery efficiencies between methods

\section{Evaluation of PEG Precipitation Using Phi6 and Coronavirus OC43 as Potential SARS-CoV-2 Surrogates}

When recovery efficiencies of Phi6 and OC43 were compared using five replicate influent samples from two WWTPs, no significant difference between the two surrogates was observed (Paired $t$ test $P$ value $=0.6137$ ). These results are in line with recovery efficiencies for OC43 as reported by Pecson et al. (2021). However, the Phi6 recovery efficiencies observed in this study were almost $2 \operatorname{logs}$ higher than the Phi6 recoveries achieved by other laboratories using the PEG method but with solids removal in the previous interlaboratory method assessment study (Pecson et al., 2021).

\section{Discussion}

This study demonstrates that Pseudomonas phage Phi6 seeded in different wastewater matrices can be concentrated and recovered by ultrafiltration-based method and PEG precipitation. In general, PEG method provided better virus recovery than the ultrafiltration-based methods as measured using RT-ddPCR. PEG precipitation is usually used as a secondary step for virus concentration in large volumes of water samples (De Keuckelaere et al., 2013; Polaczyk et al., 2008; Cuevas-Ferrando et al., 2020), but has also been used in concentrating enteric viruses directly from sewage as a primary concentration process prior to analysis by cell culture and molecular detection methods (Aw and Gin, 2010; Hovi et al., 2001; Myrmel et al., 2015; Shieh et al., 1995; Thongprachum et al., 2018). Enveloped viruses such as influenza A viruses and transmissible gastroenteritis virus (TGEV) have been detected in water samples using PEG precipitation combined with an initial filtration step (Blanco et al., 2019; Borchardt et al., 2017; Deboosere et al., 2011; Horm et al., 2012). However, only few studies have evaluated PEG

Table 4 Percent positive and mean concentrations of SARS-CoV-2 gene targets for PEG method with and without overnight incubation as measured using RT-ddPCR

\begin{tabular}{|c|c|c|c|c|c|c|}
\hline \multirow{3}{*}{$\begin{array}{l}\text { Waste- } \\
\text { water } \\
\text { Type }\end{array}$} & \multicolumn{6}{|c|}{$\%$ Positive (Mean GC per $100 \mathrm{ml} \pm \mathrm{SD}$ ) } \\
\hline & \multicolumn{3}{|c|}{ With overnight (16-h) incubation } & \multicolumn{3}{|c|}{ Without overnight incubation } \\
\hline & N1 & $\mathrm{N} 2$ & $\mathrm{E}$ & N1 & $\mathrm{N} 2$ & $\mathrm{E}$ \\
\hline $\begin{array}{l}\text { Sanitary } \\
\text { Sewer } \\
(n=15)\end{array}$ & $\begin{array}{c}33.3 \\
\left(4.36 \pm 9.21 \times 10^{3}\right)\end{array}$ & $\begin{array}{l}26.7 \\
\left(4.64 \pm 9.65 \times 10^{3}\right)\end{array}$ & $\begin{array}{l}26.7 \\
\left(3.39 \pm 6.70 \times 10^{3}\right)\end{array}$ & $\begin{array}{l}26.7 \\
\left(4.19 \pm 9.31 \times 10^{3}\right)\end{array}$ & $\begin{array}{l}26.7 \\
\left(3.95 \pm 8.80 \times 10^{3}\right)\end{array}$ & $\begin{array}{l}20 \\
\left(1.97 \pm 4.87 \times 10^{3}\right)\end{array}$ \\
\hline $\begin{array}{l}\text { WWTP } \\
\text { Influent } \\
(n=4)\end{array}$ & $\begin{array}{l}75 \\
\left(8.57 \times 10^{3} \pm 1.12 \times 10^{4}\right)\end{array}$ & $\begin{array}{l}50 \\
\left(2.0 \pm 2.15 \times 10^{3}\right)\end{array}$ & $\begin{array}{l}75 \\
\left(8.53 \pm 1.24 \times 10^{4}\right)\end{array}$ & $\begin{array}{l}75 \\
\left(3.97 \pm 3.71 \times 10^{3}\right)\end{array}$ & $\begin{array}{l}75 \\
\left(6.40 \pm 7.99 \times 10^{3}\right)\end{array}$ & $\begin{array}{l}25 \\
\left(7.92 \times 10^{2} \pm 3.39 \times 10^{1}\right)\end{array}$ \\
\hline $\begin{array}{l}\text { All } \\
(\mathrm{n}=19)\end{array}$ & $\begin{array}{l}42.1 \\
\left(5.25 \pm 9.49 \times 10^{3}\right)\end{array}$ & $\begin{array}{l}31.6 \\
\left(4.08 \pm 8.62 \times 10^{3}\right)\end{array}$ & $\begin{array}{l}36.8 \\
\left(4.47 \pm 8.06 \times 10^{3}\right)\end{array}$ & $\begin{array}{c}36.8 \\
\left(4.14 \pm 8.35 \times 10^{3}\right)\end{array}$ & $\begin{array}{c}36.8 \\
\left(4.46 \pm 8.48 \times 10^{3}\right)\end{array}$ & $\begin{array}{l}21.1 \\
\left(1.82 \pm 4.55 \times 10^{3}\right)\end{array}$ \\
\hline
\end{tabular}


precipitation as a primary concentration approach for viruses in sewage (e.g., Amdiouni et al., 2012; Hovi et al., 2001; Ye et al., 2016).

The exact mechanism of PEG precipitation of viruses from suspension is still not well understood. This could be due to that larger molecular aggregates such as viral particles are preferentially associated with inter-polymer spaces between PEG molecules and thus concentrated until their solubility is exceeded and precipitation occurs (Adams, 1973; Atha and Ingham, 1981). This may also precipitate out viruses attached to other particles in untreated wastewater which is particularly difficult to filter. Thus, this method may be better for those samples with a higher range of TSS and turbidities as evidenced by the wider range in SARS-CoV-2 N1 gene concentrations seen by Pecson et al. (2021) with PEG protocols which removed solids as compared to PEG protocols which retained solids.

In a previous study comparing three methods to concentrate enveloped murine hepatitis virus (MHV) from wastewater samples, PEG and ultracentrifugation recovered $5 \%$ of the seeded MHV, whereas the ultrafiltration produced significantly higher recovery, 25\% (Ye et al., 2016). A possible explanation to lower virus recovery efficiencies obtained with PEG precipitation could be a high salt $(\mathrm{NaCl})$ concentration $(0.5 \mathrm{M})$ added to the samples. High salt concentrations may inactivate enveloped viruses during PEG precipitation process. For example, Hamelin and Lussier, (1979) showed that infectivity of cytomegalovirus (an enveloped virus) declined from 24.7 to $6.6 \%$ as the $\mathrm{NaCl}$ concentration was progressively increased from none to $1.0 \mathrm{M} \mathrm{NaCl}$. It has also been reported that infectivity of retro- and lentiviruses decreases significantly in a high salt elution buffer $(1 \mathrm{M} \mathrm{NaCl})$ (Zimmermann et al., 2011). In this study, $0.2 \mathrm{M}$ $\mathrm{NaCl}$ was used in the PEG protocol.

The choice of PEG precipitation over other concentration methods was also based on the affordability of the procedure and the shortages of the filtration materials due to the increasing numbers of laboratories worldwide that monitor SARS-CoV-2 in wastewater. PEG precipitation is a simple and low-cost alternative (e.g., $<\$ 2$ USD per sample for PEG method vs. $>\$ 34$ USD for ultrafiltration-based method) for the concentration of viruses in wastewater without requiring any preconditioning of the sample. The PEG method used in this study has also been evaluated in a recent interlaboratory methods assessment for SARS-CoV-2 genetic signal in raw sewage using betacoronavirus OC43 as a matrix spike. By comparing 36 standard operating procedures used by 32 participating laboratories, PEG precipitation has shown a high degree of reproducibility across laboratories (Pecson et al., 2021).

Although PEG precipitation provided higher recovery efficiencies for Phi6 and SARS-CoV-2 in wastewater when compared with ultrafiltration, the protocol is slower particularly with an overnight incubation. However, in this study, the results of PEG precipitation with and without an overnight incubation for Phi6 and SARS-CoV-2 were not statistically significant. This is in agreement with other studies that reported a 2-h precipitation is sufficient for viruses (Deboosere et al., 2011; Polaczyk et al., 2008). Therefore, the PEG protocol could be shortened to increase throughput or accommodate existing analysis workflows for rapid results.

In addition to investigating recovery efficiencies of artificially seeded viruses using different concentration methods, this study compared the detection of SARS-CoV-2 genetic signals in wastewater using RT-qPCR and RT-ddPCR. Overall, RT-ddPCR showed higher sensitivity rate compared to RT-qPCR. While RT-qPCR shows equivalent detection rate of the SARS-CoV-2 N2 gene as RT-ddPCR, RT-ddPCR performed better for the $\mathrm{E}$ gene in wastewater. This may be due to RT-ddPCR allowing for greater PCR efficiency when lower concentrations of the target gene are present and its ability to cope with higher levels of inhibitory substances in wastewater. While a high number of samples in this study were found to be positive for one or more of the SARS-CoV-2 gene targets, a direct comparison of the virus concentrations between sanitary sewer and WWTP influent samples would be inaccurate due to the different sampling methods. For sanitary sewer, grab sampling was used to collect wastewater directly from manholes or lift station, whereas composite sampling technique was used for the WWTP. Different wastewater sampling techniques may influence the ability to detect and quantify viral genetic markers using PCR-based methods. For example, a grab sample taken during low flow periods may miss detecting the SARS-CoV-2 genetic markers in wastewater. A similar situation can occur for composite samples particularly for long sampling periods (e.g., $24 \mathrm{~h}$ ) as the viral signals may be diluted. Therefore, determination of the optimal sampling strategy and timing will greatly enhance the ability to accurately detect SARS-CoV-2 in wastewater. Heaton et al. (1992) showed that over $60 \%$ of men and women defecated between $5 \mathrm{am}$ and $12 \mathrm{pm}$ each day. These patterns may have changed since the study, but sample collection time is still an important factor to consider when conducting a wastewater surveillance for SARS-CoV-2.

The concentration and detection procedures outlined in this study will facilitate rapid and high-throughput detection of SARS-CoV-2 in wastewater samples. The methods were used successfully in field studies for the detection of SARSCoV-2 RNA in various wastewater samples.

Supplementary Information The online version contains supplementary material available at https://doi.org/10.1007/s12560-021-09488-8. 
Acknowledgements This research was supported by Nowlin Chair in Water Research and Michigan State University COVID-19 response funds to Dr. Joan Rose and Tulane University School of Public Health and Tropical Medicine COVID-19 Rapid Response Grant to Dr. Tiong Gim Aw. We thank Rebecca Ives at Michigan State University and all the personnel at wastewater treatment facilities for assisting in sample collection.

Funding Funding for this study was provided by Nowlin Chair in Water Research and Michigan State University COVID-19 response funds to Dr. Joan Rose and Tulane University School of Public Health and Tropical Medicine COVID-19 Rapid Response Grant to Dr. Tiong Gim Aw.

Data availability Full data are available upon request sent to corresponding author.

\section{Declarations}

Conflict of interest The authors declare no conflicts of interest nor competing interests.

\section{References}

Adams, A. (1973). Concentration of Epstein-Barr virus from cell culture fluids with polyethylene glycol. Journal of General Virology, 20, 391-394. https://doi.org/10.1099/0022-1317-20-3-391

Ahmed, W., Angel, N., Edson, J., Bibby, K., Bivins, A., O’Brien, J. W., Choi, P. M., Kitajima, M., Simpson, S. L., Li, J., Tscharke, B., Verhagen, R., Smith, W. J. M., Zaugg, J., Dierens, L., Hugenholtz, P., Thomas, K. V., \& Mueller, J. F. (2020a). First confirmed detection of SARS-CoV-2 in untreated wastewater in Australia: A proof of concept for the wastewater surveillance of COVID-19 in the community. Science of the Total Environment, 728, 138764. https://doi.org/10.1016/j.scitotenv.2020.138764

Ahmed, W., Bertsch, P. M., Angel, N., Bibby, K., Bivins, A., Dierens, L., Edson, J., Ehret, J., Gyawali, P., Hamilton, K., Hosegood, I., Hugenholtz, P., Jiang, G., Kitajima, M., Sichani, H. T., Shi, J., Shimko, K. M., Simpson, S. L., Smith, W. J. M., ... DSC, K.V.T., Verhagen, R., Zaugg, J., Mueller, J.F., . (2020b). Detection of SARS-CoV-2 RNA in commercial passenger aircraft and cruise ship wastewater: a surveillance tool for assessing the presence of COVID-19 infected travelers. Journal of Travel Medicine, 27, taaa116. https://doi.org/10.1093/jtm/taaa116

Ahmed, W., Bertsch, P. M., Bivins, A., Bibby, K., Farkas, K., Gathercole, A., Haramoto, E., Gyawali, P., Korajkic, A., McMinn, B. R., Mueller, J. F., Simpson, S. L., Smith, W. J. M., Symonds, E. M., Thomas, K. V., Verhagen, R., \& Kitajima, M. (2020c). Comparison of virus concentration methods for the RT-qPCR-based recovery of murine hepatitis virus, a surrogate for SARS-CoV-2 from untreated wastewater. Science of the Total Environment, 739, 139960. https://doi.org/10.1016/j.scitotenv.2020.139960

Amdiouni, H., Maunula, L., Hajjami, K., Faouzi, A., Soukri, A., \& Nourlil, J. (2012). Recovery comparison of two virus concentration methods from wastewater using cell culture and real-time PCR. Current Microbiology, 65, 432-437. https://doi.org/10. 1007/s00284-012-0174-8

Ampuero, M., Valenzuela, S., Valiente-Echeverria, F., Soto-Rifo, R., Barriga, G. P., Chnaiderman, J., Rojas, C., Guajardo-Leiva, S., Diez, B., \& Gaggero, A. (2020). SARS-CoV-2 detection in sewage in Santiago. Chile - Preliminary Results. Medrxiv Preprint. https://doi.org/10.1101/2020.07.02.20145177
Arora, S., Nag, A., Sethi, J., Rajvanshi, J., Saxena, S., Shrivastava, S. K., \& Gupta, A. B. (2020). Sewage surveillance for the presence of SARS-CoV-2 genome as a useful wastewater based epidemiology (WBE) tracking tool in India. medRxiv. https://doi.org/10. $1101 / 2020.06 .18 .20135277$

Atha, D. H., \& Ingham, K. C. (1981). Mechanism of precipitation of proteins by polyethylene glycols. Analysis in terms of excluded volume. Journal of Biological Chemistry, 256, 12108-12117.

Aw, T. G., \& Gin, K.Y.-H. (2010). Environmental surveillance and molecular characterization of human enteric viruses in tropical urban wastewaters. Journal of Applied Microbiology, 109, 716730. https://doi.org/10.1111/j.1365-2672.2010.04701.x

Balboa, S., Mauricio-Iglesias, M., Rodríguez, S., Martínez-Lamas, L., Vasallo, F. J., Regueiro, B., \& Lema, J. M. (2020). The fate of SARS-CoV-2 in wastewater treatment plants points out the sludge line as a suitable spot for incidence monitoring. medRxiv. https:// doi.org/10.1101/2020.05.25.20112706

Barcelo, D. (2020). An environmental and health perspective for COVID-19 outbreak: Meteorology and air quality influence, sewage epidemiology indicator, hospitals disinfection, drug therapies and recommendations. Journal of Environmental Chemical Engineering, 8, 104006. https://doi.org/10.1016/j.jece.2020.104006

Bar-Or, I., Yaniv, K., Shagan, M., Ozer, E., Erster, O., Mendelson, E., Mannasse, B., Shirazi, R., Kramarsky-Winter, E., Nir, O., AbuAli, H., Ronen, Z., Rinott, E., Lewis, Y. E., Friedler, E., Bitkover, E., Paitan, Y., Berchenko, Y., \& Kushmaro, A. (2020). Regressing SARS-CoV-2 sewage measurements onto COVID-19 burden in the population: A proof-of-concept for quantitative environmental surveillance. medRxiv. https://doi.org/10.1101/2020.04.26.20073 569

Blanco, A., Abid, I., Al-Otaibi, N., Pérez-Rodríguez, F. J., Fuentes, C., Guix, S., Pintó, R. M., \& Bosch, A. (2019). Glass wool concentration optimization for the detection of enveloped and nonenveloped waterborne viruses. Food Environ Virol, 11, 184-192. https://doi.org/10.1007/s12560-019-09378-0

Borchardt, M. A., Spencer, S. K., Hubbard, L. E., Firnstahl, A. D., Stokdyk, J. P., \& Kolpin, D. W. (2017). Avian influenza virus RNA in groundwater wells supplying poultry farms affected by the 2015 influenza outbreak. Environ Sci Tech Let, 4, 268-272. https://doi.org/10.1021/acs.estlett.7b00128

de Carvalho, N. A., Stachler, E. N., Cimabue, N., \& Bibby, K. (2017). Evaluation of Phi6 persistence and suitability as an enveloped virus surrogate. Environmental Science and Technology, 51, 8692-8700. https://doi.org/10.1021/acs.est.7b01296

Chavarria-Miró, G., Anfruns-Estrada, E., Guix, S., Paraira, M., Galofré, B., Sáanchez, G., Pintó, R., \& Bosch, A. (2020). Sentinel surveillance of SARS-CoV-2 in wastewater anticipates the occurrence of COVID-19 cases. medRxiv. https://doi.org/10.1101/2020. 06.13.20129627

Corman, V. M., Landt, O., Kaiser, M., Molenkamp, R., Meijer, A., Chu, D. K., Bleicker, T., Brünink, S., Schneider, J., Schmidt, M. L., Mulders, D. G., Haagmans, B. L., van der Veer, B., van den Brink, S., Wijsman, L., Goderski, G., Romette, J.-L., Ellis, J., Zambon, M., ... Drosten, C. (2020). Detection of 2019 novel coronavirus (2019-nCoV) by real-time RT-PCR. Eurosurveillance, 25, 2000045. https://doi.org/10.2807/1560-7917.es.2020. 25.3.2000045

Cuevas-Ferrando, E., Pérez-Cataluña, A., Allende, A., Guix, S., Randazzo, W., \& Sánchez, G. (2020). Recovering coronavirus from large volumes of water. Science of the Total Environment, 762, 143101. https://doi.org/10.1016/j.scitotenv.2020.143101

Curtis, K., Keeling, D., Yetka, K., Larson, A., \& Gonzalez, R. (2020). Wastewater SARS-CoV-2 concentration and loading variability from grab and 24-hour composite samples. medRxiv. https://doi. org/10.1101/2020.07.10.20150607 
Deboosere, N., Horm, S. V., Pinon, A., Gachet, J., Coldefy, C., Buchy, P., \& Vialette, M. (2011). Development and validation of a concentration method for the detection of influenza A viruses from large volumes of surface water. Appl Environ Microb, 77, 38023808. https://doi.org/10.1128/aem.02484-10

Döhla, M., Wilbring, G., Schulte, B., Kümmerer, B. M., Diegmann, C., Sib, E., Richter, E., Haag, A., Engelhart, S., Eis-Hübinger, A. M., Exner, M., Streeck, H., \& Schmithausen, R. M. (2020). SARS-CoV-2 in environmental samples of quarantined households. medRxiv. https://doi.org/10.1101/2020.05.28.20114041

Fongaro, G., Stoco, P. H., Souza, D. S. M., Grisard, E. C., Magri, M. E., Rogovski, P., Schorner, M. A., Barazzetti, F. H., Christoff, A. P., de Oliveira, L. F. V., Bazzo, M. L., Wagner, G., Hernandez, M., \& Rodriguez-Lazaro, D. (2020). SARS-CoV-2 in human sewage in Santa Catalina, Brazil, November 2019. medRxiv. https://doi. org/10.1101/2020.06.26.20140731

Gendron, L., Verreault, D., Veillette, M., Moineau, S., \& Duchaine, C. (2010). Evaluation of filters for the sampling and quantification of RNA phage aerosols. Aerosol Science and Technology, 44, 893-901. https://doi.org/10.1080/02786826.2010.501351

Gonzalez, R., Curtis, K., Bivins, A., Bibby, K., Weir, M. H., Yetka, K., et al. (2020). COVID-19 surveillance in Southeastern Virginia using wastewater-based epidemiology. Water Research, 186, 116296. https://doi.org/10.1016/j.watres.2020.116296

Green, H., Wilder, M., Middleton, F. A., Collins, M., Fenty, A., Gentile, K., Kmush, B., Zeng, T., \& Larsen, D. A. (2020). Quantification of SARS-CoV-2 and cross-assembly phage (crAssphage) from wastewater to monitor coronavirus transmission within communities. medRxiv. https://doi.org/10.1101/2020.05.21.20109181

Guerrero-Latorre, L., Ballesteros, I., Villacres, I., Granda-Albuja, M. G., Freire, B., \& Rios-Touma, B. (2020). First SARS-CoV-2 detection in river water: Implications in low sanitation countries. medRxiv. https://doi.org/10.1101/2020.06.14.20131201

Hamelin, C., \& Lussier, G. (1979). Concentration of human cytomegalovirus from large volumes of tissue culture fluids. Journal of General Virology, 42, 193-197. https://doi.org/10.1099/ 0022-1317-42-1-193

Haramoto, E., Kitajima, M., Hata, A., Torrey, J. R., Masago, Y., Sano, D., \& Katayama, H. (2018). A review on recent progress in the detection methods and prevalence of human enteric viruses in water. Water Research, 135, 168-186. https://doi.org/10.1016/j. watres.2018.02.004

Haramoto, E., Malla, B., Thakali, O., \& Kitajima, M. (2020). First environmental surveillance for the presence of SARS-CoV-2 RNA in wastewater and river water in Japan. Science of the Total Environment, 737, 140405. https://doi.org/10.1016/j.scitotenv.2020. 140405

Hata, A., Honda, R., Hara-Yamamura, H., \& Meuchi, Y. (2020). Detection of SARS-CoV-2 in wastewater in Japan by multiple molecular assays-implication for wastewater-based epidemiology (WBE). medRxiv. https://doi.org/10.1101/2020.06.09.20126417

Heaton, K. W., Radvan, J., Cripps, H., Mountford, R. A., Braddon, F. E., \& Hughes, A. O. (1992). Defecation frequency and timing, and stool form in the general population: A prospective study. Gut, 33, 818. https://doi.org/10.1136/gut.33.6.818

Horm, S. V., Gutiérrez, R. A., Sorn, S., \& Buchy, P. (2012). Environment: A potential source of animal and human infection with influenza A (H5N1) virus. Influenza Other Resp, 6, 442-448. https://doi.org/10.1111/j.1750-2659.2012.00338.x

Hovi, T., Stenvik, M., Partanen, H., \& Kangas, A. (2001). Poliovirus surveillance by examining sewage specimens. Quantitative recovery of virus after introduction into sewerage at remote upstream location. Epidemiology and Infection, 127, 101-106. https://doi. org/10.1017/s0950268801005787

Jorgensen, A. U., Gamst, J., Hansen, L. V., Knudsen, I. I. H., \& Jensen, S. K. S. (2020). Eurofins Covid-19 sentinel TM wastewater test provide early warning of a potential COVID-19 outbreak. medRxiv. https://doi.org/10.1101/2020.07.10.20150573

Keuckelaere, A. D., Baert, L., Duarte, A., Stals, A., \& Uyttendaele, M. (2013). Evaluation of viral concentration methods from irrigation and processing water. Journal of Virological Methods, 187, 294-303. https://doi.org/10.1016/j.jviromet.2012.11.028

Kocamemi, B. A., Kurt, H., Hacioglu, S., Yaralı, C., Saatci, A. M., \& Pakdemirli, B. (2020a). First data-set on SARS-CoV-2 detection for Istanbul Wastewaters in Turkey. medRxiv. https://doi.org/10. 1101/2020.05.03.20089417

Kocamemi, B. A., Kurt, H., Sait, A., Sarac, F., Saatci, A. M., \& Pakdemirli, B. (2020b). SARS-CoV-2 detection in Istanbul wastewater treatment plant sludges. medRxiv. https://doi.org/10.1101/ 2020.05.12.20099358

Kumar, M., Patel, A. K., Shah, A. V., Raval, J., Rajpara, N., Joshi, M., \& Joshi, C. G. (2020). The first proof of the capability of wastewater surveillance for COVID-19 in India through the detection of the genetic material of SARS-CoV-2. medRxiv. https://doi.org/ 10.1101/2020.06.16.20133215

LaTurner, Z. W., Zong, D. M., Kalvapalle, P., Gamas, K. R., Terwilliger, A., Crosby, T., et al. (2021). Evaluating recovery, cost, and throughput of different concentration methods for SARS-CoV-2 wastewater-based epidemiology. Water Research, 197, 117043. https://doi.org/10.1016/j.watres.2021.117043

Lu, X., Wang, L., Sakthivel, S. K., Whitaker, B., Murray, J., Kamili, S., et al. (2020). US CDC real-time reverse transcription PCR panel for detection of severe acute respiratory syndrome coronavirus 2 . Emerging Infectious Diseases, 26(8), 1654-1665. https://doi.org/ 10.3201/eid2608.201246

Medema, G., Heijnen, L., Elsinga, G., Italiaander, R., \& Brouwer, A. (2020). Presence of SARS-Coronavirus-2 RNA in sewage and correlation with reported COVID-19 prevalence in the early stage of the epidemic in The Netherlands. Environmental Science \& Technology Letters, 7, 511-516. https://doi.org/10.1021/acs.estle tt.0c00357

Mera, I. G. F. D., Río, F. J. R. D., Fuente, J. D. L., Sancho, M. P., Hervas, D., Moreno, I., Dominguez, M., Domínguez, L., Gortázar, C., 2020. COVID-19 in a rural community: Outbreak dynamics, contact tracing and environmental RNA. medRxiv. https://doi.org/ 10.20944/preprints202005.0450.v1

Miyani, B., Fonoll, X., Norton, J., Mehrotra, A., \& Xagoraraki, I. (2020). SARS-CoV-2 in detroit wastewater. Journal of Environmental Engineering, 146, 06020004. https://doi.org/10.1061/ (asce)ee.1943-7870.0001830

Myrmel, M., Lange, H., \& Rimstad, E. (2015). A 1-year quantitative survey of noro-, adeno-, human boca-, and hepatitis E viruses in raw and secondarily treated sewage from two plants in Norway. Food Environ Virol, 7, 213-223. https://doi.org/10.1007/ s12560-015-9200-x

Nemudryi, A., Nemudraia, A., Surya, K., Wiegand, T., Buyukyoruk, M., Wilkinson, R., \& Wiedenheft, B. (2020). Temporal detection and phylogenetic assessment of SARS-CoV-2 in municipal wastewater. Medrxiv Prepr Serv Heal Sci. https://doi.org/10.1101/ 2020.04.15.20066746

Park, S., Lee, C.-W., Park, D.-I., Woo, H.-Y., Cheong, H. S., Shin, H. C., Ahn, K., Kwon, M.-J., \& Joo, E.-J. (2020). Detection of SARS-CoV-2 in fecal samples from patients with asymptomatic and mild COVID-19 in Korea. Clinical Gastroenterology $H$. https://doi.org/10.1016/j.cgh.2020.06.005

Peccia, J., Zulli, A., Brackney, D. E., Grubaugh, N. D., Kaplan, E. H., Casanovas-Massana, A., Ko, A. I., Malik, A. A., Wang, D., Wang, M., Warren, J. L., Weinberger, D. M., \& Omer, S. B. (2020). SARS-CoV-2 RNA concentrations in primary municipal sewage sludge as a leading indicator of COVID-19 outbreak dynamics. medRxiv. https://doi.org/10.1101/2020.05.19.20105999 
Pecson, B. M., Darby, E., Haas, C. N., Amha, Y. M., Bartolo, M., Danielson, R., et al. (2021). Reproducibility and sensitivity of 36 methods to quantify the SARS-CoV-2 genetic signal in raw wastewater: findings from an interlaboratory methods evaluation in the US. Environmental Science: Water Research \& Technology, 7(3), 504-520. https://doi.org/10.1039/d0ew00946f

Polaczyk, A. L., Narayanan, J., Cromeans, T. L., Hahn, D., Roberts, J. M., Amburgey, J. E., \& Hill, V. R. (2008). Ultrafiltration-based techniques for rapid and simultaneous concentration of multiple microbe classes from 100-L tap water samples. Journal of Microbiological Methods, 73, 92-99. https://doi.org/10.1016/j.mimet.2008.02.014

Prado, T., Fumian, T. M., Mannarino, C. F., Maranhão, A. G., Siqueira, M. M., \& Miagostovich, M. P. (2020). Preliminary results of SARS$\mathrm{CoV}-2$ detection in sewerage system in Niterói municipality, Rio de Janeiro, Brazil. Memórias Instituto Oswaldo Cruz, 115, e200196. https://doi.org/10.1590/0074-02760200196

Randazzo, W., Cuevas-Ferrando, E., Sanjuán, R., Domingo-Calap, P., \& Sánchez, G. (2020a). Metropolitan wastewater analysis for COVID19 epidemiological surveillance. International Journal of Hygiene and Environmental Health, 230, 113621. https://doi.org/10.1016/j. ijheh.2020.113621

Randazzo, W., Truchado, P., Cuevas-Ferrando, E., Simón, P., Allende, A., \& Sánchez, G. (2020b). SARS-CoV-2 RNA in wastewater anticipated COVID-19 occurrence in a low prevalence area. Water Research, 181, 115942. https://doi.org/10.1016/j.watres.2020. 115942

Rimoldi, S. G., Stefani, F., Gigantiello, A., Polesello, S., Comandatore, F., Mileto, D., Maresca, M., Longobardi, C., Mancon, A., Romeri, F., Pagani, C., Moja, L., Gismondo, M. R., \& Salerno, F. (2020). Presence and vitality of SARS-CoV-2 virus in wastewaters and rivers. medRxiv. https://doi.org/10.1101/2020.05.01.20086009

La Rosa, G., Bonadonna, L., Lucentini, L., Kenmoe, S., \& Suffredini, E. (2020a). Coronavirus in water environments: Occurrence, persistence and concentration methods - A scoping review. Water Research, 179, 115899. https://doi.org/10.1016/j.watres.2020. 115899

La Rosa, G., Iaconelli, M., Mancini, P., Ferraro, G. B., Veneri, C., Bonadonna, L., Lucentini, L., \& Suffredini, E. (2020b). First detection of SARS-CoV-2 in untreated wastewaters in Italy. Science of the Total Environment, 736, 139652. https://doi.org/10.1016/j.scitotenv. 2020.139652

La Rosa, G., Mancini, P., Ferraro, G. B., Veneri, C., Iaconelli, M., Bonadonna, L., Lucentini, L., \& Suffredini, E. (2020c). SARS-CoV-2 has been circulating in northern Italy since December 2019: evidence from environmental monitoring. medRxiv. https://doi.org/10.1101/ 2020.06.25.20140061

Sharif, S., Ikram, A., Khurshid, A., Salman, M., Mehmood, N., Arshad, Y., Ahmad, J., Angez, M., Alam, M. M., Rehman, L., Mujtaba, G., Hussain, J., Ali, J., Akthar, Ri., Malik, M. W., Baig, Z. I., Rana, M. S., Usman, M., Ali, M. Q., ... Ali, N. (2020). Detection of SARSCoronavirus-2 in wastewater, using the existing environmental surveillance network: An epidemiological gateway to an early warning for COVID-19 in communities. medRxiv. https://doi.org/10.1101/ 2020.06.03.20121426

Sherchan, S. P., Shahin, S., Ward, L. M., Tandukar, S., Aw, T. G., Schmitz, B., Ahmed, W., \& Kitajima, M. (2020). First detection of SARS-CoV-2 RNA in wastewater in North America: A study in Louisiana, USA. Science of the Total Environment, 743, 140621. https://doi.org/10.1016/j.scitotenv.2020.140621

Shieh, Y.-S.C., Wait, D., Tai, L., \& Sobsey, M. D. (1995). Methods to remove inhibitors in sewage and other fecal wastes for enterovirus detection by the polymerase chain reaction. Journal of Virological Methods, 54, 51-66. https://doi.org/10.1016/0166-0934(95)00025-p
Thongprachum, A., Fujimoto, T., Takanashi, S., Saito, H., Okitsu, S., Shimizu, H., Khamrin, P., Maneekarn, N., Hayakawa, S., \& Ushijima, H. (2018). Detection of nineteen enteric viruses in raw sewage in Japan. Infect Genetics Evol, 63, 17-23. https://doi.org/10.1016/j. meegid.2018.05.006

Trottier, J., Darques, R., Mouheb, N. A., Partiot, E., Bakhache, W., Deffieu, M. S., \& Gaudin, R. (2020). Post-lockdown detection of SARSCoV-2 RNA in the wastewater of Montpellier. France. One Heal, 10, 100157. https://doi.org/10.1016/j.onehlt.2020.100157

Vallejo, J. A., Rumbo-Feal, S., Conde-Pérez, K., López-Oriona, Á., Tarrío-Saavedra, J., Reif, R., Ladra, S., Rodiño-Janeiro, B. K., Nasser, M., Cid, Á., Veiga, M. C., Acevedo, A., Lamora, C., Bou, G., Cao, R., \& Poza, M. (2020). Predicting the number of people infected with SARS-COV-2 in a population using statistical models based on wastewater viral load. medRxiv. https://doi.org/10.1101/2020.07. 02.20144865

Vidaver, A. K., Koski, R. K., \& Etten, J. L. V. (1973). Bacteriophage $\varphi 6$ : A lipid-containing virus of Pseudomonas phaseolicola1. Journal of Virology, 11, 799-805. https://doi.org/10.1128/jvi.11.5.799-805. 1973

Wang, J., Feng, H., Zhang, S., Ni, Z., Ni, L., Chen, Y., Zhuo, L., Zhong, Z., \& Qu, T. (2020). SARS-CoV-2 RNA detection of hospital isolation wards hygiene monitoring during the Coronavirus disease 2019 outbreak in a Chinese hospital. International Journal of Infectious Diseases, 94, 103-106. https://doi.org/10.1016/j.ijid.2020.04.024

Weidhaas, J., Aanderud, Z., Roper, D., VanDerslice, J., Gaddis, E., Ostermiller, J., Hoffman, K., Jamal, R., Heck, P., Zhang, Y., Torgersen, K., Laan, J. V., \& LaCross, N., (2020). Correlation of SARS-CoV-2 RNA in wastewater with COVID-19 disease burden in sewersheds. https://doi.org/10.21203/rs.3.rs-40452/v1

Westhaus, S., Weber, F. -A., Schiwy, S., Linnemann, V., Brinkmann, M., Widera, M., Greve, C., Janke, A., Hollert, H., Wintgens, T., \& Ciesek, S., (2021). Detection of SARS-CoV-2 in raw and treated wastewater in Germany - Suitability for COVID-19 surveillance and potential transmission risks. Science of the Total Environment, 751, 141750. https://doi.org/10.1016/j.scitotenv.2020.141750

Wu, F., Xiao, A., Zhang, J., Moniz, K., Endo, N., Armas, F., Bonneau, R., Brown, M. A., Bushman, M., Chai, P. R., Duvallet, C., Erickson, T. B., Foppe, K., Ghaeli, N., Gu, X., Hanage, W. P., Huang, K. H., Lee, W. L., Matus, M., ... Alm, E. J. (2020a). SARS-CoV-2 titers in wastewater foreshadow dynamics and clinical presentation of new COVID-19 cases. Medrxiv. https://doi.org/10.1101/2020.06. 15.20117747

Wu, Y., Guo, C., Tang, L., Hong, Z., Zhou, J., Dong, X., Yin, H., Xiao, Q., Tang, Y., Qu, X., Kuang, L., Fang, X., Mishra, N., Lu, J., Shan, H., Jiang, G., \& Huang, X. (2020b). Prolonged presence of SARSCoV-2 viral RNA in faecal samples. Lancet Gastroenterology Hepatology, 5, 434-435. https://doi.org/10.1016/s2468-1253(20)30083-2

Wurtzer, S., Marechal, V., Mouchel, J., Maday, Y., Teyssou, R., Richard, E., Almayrac, J., \& Moulin, L. (2020). Evaluation of lockdown impact on SARS-CoV-2 dynamics through viral genome quantification in Paris wastewaters. medRxiv. https://doi.org/10.1101/2020. 04.12.20062679

Ye, Y., Ellenberg, R. M., Graham, K. E., \& Wigginton, K. R. (2016). Survivability, partitioning, and recovery of enveloped viruses in untreated municipal wastewater. Environmental Science and Technology, 50, 5077-5085. https://doi.org/10.1021/acs.est.6b00876

Zhang, D., Ling, H., Huang, X., Li, J., Li, W., Yi, C., Zhang, T., Jiang, Y., He, Y., Deng, S., Zhang, X., Liu, Y., Li, G., \& Qu, J. (2020a). Potential spreading risks and disinfection challenges of medical wastewater by the presence of severe acute respiratory syndrome coronavirus 2 (SARS-CoV-2) viral RNA in septic tanks of fangcang hospital. medRxiv. https://doi.org/10.1101/2020.04.28.20083832 
Zhang, D., Yang, Y., Huang, X., Jiang, J., Li, M., Zhang, X., Ling, H., Li, J., Liu, Y., Li, G., Li, W., Yi, C., Zhang, T., Jiang, Y., Xiong, Y., Hu, Z., Wang, X., Deng, S., Zhao, P., \& Qu, J. (2020b). SARS-CoV-2 spillover into hospital outdoor environments. medRxiv. https://doi. org/10.1101/2020.05.12.20097105

Zhou, J.-B., Kong, W.-H., Wang, S., Long, Y.-B., Dong, L.-H., He, Z.-Y., \& Liu, M.-Q. 2020. Potential transmission risk of SARS-CoV-2 through medical wastewater in COVID-19 outbreak cities. https:// doi.org/10.21203/rs.3.rs-3743/v1

Zimmermann, K., Scheibe, O., Kocourek, A., Muelich, J., Jurkiewicz, E., \& Pfeifer, A. (2011). Highly efficient concentration of lenti- and retroviral vector preparations by membrane adsorbers and ultrafiltration. BMC Biotechnology, 11, 55. https://doi.org/10.1186/ 1472-6750-11-55

Publisher's Note Springer Nature remains neutral with regard to jurisdictional claims in published maps and institutional affiliations. 